\title{
The protective role of resveratrol against zinc oxide induced nanotoxicity
}

\author{
Bugrahan EMSEN ${ }^{1 *}$, Hasan TURKEZ ${ }^{2}$ \\ ${ }^{1}$ Department of Biology, Kamil Özdă̆ Faculty of Science, Karamanoğlu Mehmetbey University, Karaman, \\ Turkey \\ ${ }^{2}$ Department of Molecular Biology and Genetics, Faculty of Science, Erzurum Technical University, Erzurum, \\ Turkey \\ *bugrahanemsen@gmail.com
}

\section{Resveratrolün çinko oksit indüklü nanotoksisiteye karşı koruyucu rolü}

\begin{abstract}
Zinc oxide $(\mathrm{ZnO})$ is a compound that has harmful effects as well as being used in many different areas. Numerous studies have been carried out to minimize the toxic effects of $\mathrm{ZnO}$ nanoparticles (NPs). In the present study, the protective role of resveratrol (RSV), a potent antioxidant polyphenol substance, was examined against $\mathrm{ZnO}$-induced nanotoxicity on human pulmonary alveolar epithelial cells (HPAEpiC). In this context, the cytotoxic and genotoxic effects of different concentrations of RSV $(5,10,20 \mathrm{mg} / \mathrm{L})$ and $\mathrm{ZnO}$ NPs on the cells were measured alone and in combination. At the same time, the effects of aforementioned applications on the total antioxidant capacity (TAC) level in HPAEpiC were assessed. The results obtained showed that ZnO NPs alone significantly increased cytotoxicity and genotoxicity on cells compared to negative control (control $(-))$. In the experiments performed with $\mathrm{RSV}+\mathrm{ZnO} \mathrm{NP}$ combination, cytotoxic and genotoxic activity decreased at the level of $p<0.05$ especially at $20 \mathrm{mg} / \mathrm{L}$ application of RSV. When the level of TAC in cells was examined, a concentration-dependent increase was detected between TAC and RSV. It was determined that ZnO NPs reduced the TAC level statistically $(p<0.05)$ in comparison with control (-). In conclusion, the present study revealed that RSV, a natural antioxidant, showed protective property against genotoxic and cytotoxic damage induced by ZnO NPs on HPAEpiC.
\end{abstract}

Key words: Antioxidant, Nanotoxicity, Resveratrol, Zinc oxide

\begin{abstract}
Özet: Çinko oksit ( $\mathrm{ZnO})$ birçok farklı alanda kullanılmakla beraber zararlı etkileri de olan bir bileşiktir. ZnO nanopartiküllerinin (NPler) gösterdiği toksik etkileri en az seviyeye indirmek için çok sayıda çalışma gerçekleștirilmektedir. Mevcut çalıșmada, güçlü bir antioksidan polifenol madde olan resveratrolün (RSV) insan akciğer alveol epitel hücreleri (İAAEpiH) üzerinde $\mathrm{ZnO}$ indüklü nanotoksisiteye karşı koruyucu rolü incelenmiștir. Bu kapsamda, RSV'nin farklı konsantrasyonlarının (5, 10, 20 mg/L) ve $\mathrm{ZnO}$ NPler'in hücreler üzerindeki sitotoksik ve genotoksik etkileri tek başlarına ve kombine olarak ölçülmüştür. Aynı zamanda, bahsi geçen uygulamaların İAAEpiH'deki toplam antioksidan kapasite (TAK) düzeyine etkileri değerlendirilmiștir. Elde edilen sonuçlar, ZnO NPler'in tek başına hücreler üzerinde sitotoksisite ve genotoksisiteyi negatif kontrole (kontrol (-)) kıyasla önemli derecede yükselttiğini göstermiştir. RSV + ZnO NP kombineli gerçekleştirilen denemelerde, özellikle RSV'nin $20 \mathrm{mg} / \mathrm{L}$ 'lik uygulamasında sitotoksik ve genotoksik aktivite $p<0.05$ seviyesinde düşmüştür. Hücrelerdeki TAK seviyesi incelendiğinde, TAK ile RSV arasında konsantrasyona bağlı bir artış tespit edilmiştir. ZnO NPlerin ise TAK düzeyini kontrol ()'ye kıyasla istatistiki $(p<0.05)$ açıdan yüksek derecede düşürdüğü belirlenmiştir. Sonuç olarak, mevcut çalışma, doğal bir antioksidan olan RSV'nin İAAEpiH'leri üzerinde $\mathrm{ZnO}$ NPleri tarafindan indüklenen genotoksik ve sitotoksik hasara karș1 koruyucu özellik gösterdiğini ortaya çıkarmıştır.
\end{abstract}

Anahtar Kelimeler: Antioksidan, Nanotoksisite, Resveratrol, Çinko oksit

\section{Introduction}

Zinc oxide $(\mathrm{ZnO})$ has very key properties. This compound has many industrial applications due to its unique properties such as high refractive index, high thermal conductivity, antibacterial property and low expansion coefficient (Moezzi et al., 2012). ZnO has proven itself in many sectors such as porcelain, ceramic, rubber, paint, cosmetics, paint, fertilizer, ink and flame retardant. $\mathrm{ZnO}$ containing creams are used to aid to the treatment of sunburn, insect bites and itchiness, rashes and skin irritations (Özgür et al., 2005). On the other hand, side effects of $\mathrm{ZnO}$-containing products can not be overlooked. Especially cosmetic products containing $\mathrm{ZnO}$ nanomaterials have a significant risk of absorption. Toxicology studies have shown that nanomaterials can have various side effects on the central nervous system, the immune system and the lungs (Dwivedi et al., 2009; Zhao and Castranova, 2011).

The most important entry and target organ of the nanoparticles (NPs) in the human body is the lungs. It is well known that the lungs are easily exposed to NP materials (Kendall and Holgate, 2012). One of the main mechanisms of lung damage caused by NPs that are formed as a result of burning is the oxidative stress. Brown et al. (2001) reported that there is a significant correlation between the surface area of NPs and the inflammation caused by oxidative stress. It has also been determined that high-size NPs cause genotoxicity (Donaldson et al., 2010). Antioxidants, especially those of herbal origin, play an important role in reducing of oxidative stress and genetic damage in human body (Birben et al., 2012). Resveratrol (RSV) is one of these important natural components. RSV in the phytoalexin group is obtained as a secondary metabolite from different plants. The rate of this compound is especially high in Vitis vinifera L. bark (Savouret and Quesne, 2002). RSV with antioxidant activity inhibits the progression of vascular stiffness by inhibiting low density lipoprotein oxidation and reduces lipid peroxidation and reduces lipid peroxidation and production of reactive oxygen species (King et al., 2006). 
Based on high antioxidant properties of RSV, in the present study, the toxicity induced by $\mathrm{ZnO}$ and the possible beneficial effect of $\mathrm{RSV}$ against $\mathrm{ZnO}$-induced cyototoxicity and genotoxicity were investigated.

\section{Materials and Method}

\subsection{NP Synthesis and Characterization}

ZnO NPs were synthesized by direct precipitation method using zinc nitrate and $\mathrm{KOH}$ as precursors as previously described (Ghorbani et al., 2015). For the synthesis, zinc nitrate hexahydrate $\left(\mathrm{Zn}\left(\mathrm{NO}_{3}\right)_{2} \cdot 6 \mathrm{H}_{2} \mathrm{O}\right)$ and $\mathrm{KOH}$ solutions were prepared using deionized water. The $\mathrm{KOH}$ was slowly added into $\mathrm{Zn}\left(\mathrm{NO}_{3}\right)_{2} \cdot 6 \mathrm{H}_{2} \mathrm{O}$ solution at room temperature under stirring, which resulted in the formation of a white suspension. The white product was centrifuged at $5000 \mathrm{rpm}$ for $25 \mathrm{~min}$ and washed three times with distilled water, and one time with absolute alcohol. The obtained product was calcined at $500^{\circ} \mathrm{C}$ for $4 \mathrm{~h}$. Characterization of NPs UV-Vis spectroscopy was used to prove the existence of nanoparticles. The NPs were characterized by X-ray diffraction (XRD). The average crystallite sizes of the $\mathrm{ZnO}$ NPs were calculated from the full width at half maximum of XRD peaks by using Debye-Scherrer's formula and were found to be between $50-100 \mathrm{~nm}$.

\subsection{Antioxidant Compound}

RSV (Cas: 501-36-0, $\mathrm{C}_{14} \mathrm{H}_{12} \mathrm{O}_{3}$ ) that used in this investigation as an antioxidant agent was obtained from Sigma-Aldrich, Germany.

\subsection{Cell Cultures and Treatments}

Human pulmonary alveolar epithelial cells (HPAEpiC) was provided from American Type Culture Collection (ATCC, USA). The cells were grown and maintained in Alveolar Epithelial Cell Medium (AEpiCM) consists of $500 \mathrm{ml}$ of basal medium, $10 \mathrm{ml}$ of fetal bovine serum, 5 $\mathrm{ml}$ of epithelial cell growth supplement and $5 \mathrm{ml}$ of penicillin-streptomycin at $37^{\circ} \mathrm{C}$ in a $90 \%$ humidified incubator with $5 \% \mathrm{CO}_{2}$.

\subsection{Testing Cytotoxicity, Genotoxicity and Oxidative Alterations}

For 3-(4,5-dimethylthiazol-2-yl)-2,5-diphenyltetrazolium bromide (MTT) assay, the cells were cultured in in 48well plates. Cells were incubated at $37^{\circ} \mathrm{C}$ in a humidified $5 \% \mathrm{CO}_{2} / 95 \%$ air mixture and treated with $\mathrm{ZnO}$ NPs (100 $\mathrm{mg} / \mathrm{L}$ ) and RSV (5 (RSV 1), 10 (RSV 2) and 20 (RSV 3) $\mathrm{mg} / \mathrm{L}$ ) for $72 \mathrm{~h}$ (Turkez et al., 2016a; Oztetik et al., 2017). In all assays, dimethyl sulfoxide (DMSO) + relevant cell culture medium (2\% DMSO) was used as negative control (control (-)). MTT substrate solution was used according to the manufacturer's instructions (EMD Millipore Corporation, USA). In MTT assays, $1 \%$ Triton-X was used as positive control (control (+)).

8-hydroxy-2'-deoxyguanosine (8-OH-dG) assay kits were purchased from Cayman Chemical (Ann Arbor, MI, USA) for determining 8-OH-dG levels in cultures. All procedures were carried out in accordance with the provider's manual (Turkez et al., 2016b). In genotoxicity assays, mitomycin-C $\left(10^{-7} \mathrm{M}\right)$ was used as control (+).

The automated Trolox equivalent total antioxidant capacity (TAC) assay was carried out by commercially available kits (Rel Assay Diagnostics, Turkey) (Emsen et al., 2017). In TAC assays, ascorbic acid (20 mg/L) was used as control (+).

\subsection{Statistical Analyses}

All the assays were carried out at least in triplicate measurements. Protective abilities of antioxidant agent were analyzed using variance (ANOVA) test followed by appropriate post-hoc test (Duncan test) and values with $p$ $<0.05$ were considered as significantly different. Hierarchical cluster analysis (HCA) with Ward's minimum variance method was utilized to investigate the similarities and dissimilarities among the cytotoxic effects. All analyses were performed using Statistical Package for Social Sciences (SPSS, version 21.0, IBM Corporation, Armonk, NY, USA).

\section{Results}

\subsection{Cytotoxicity activities}

The results of the present study showed that control (+) caused maximum cytotoxicity $(85.43 \%)$ on HPAEpiC. Next high cytotoxicity $(51.79 \%)$ value belonged to $\mathrm{ZnO}$ NPs. The effects of RSV treatments on viability of the cells were high. Important statistical significances in the reduction of cell viabilities were found in the cultures concomitantly treated with RSV and $\mathrm{ZnO} \mathrm{NPs}$ as compared to the group $\mathrm{ZnO}$ NPs treated alone. Cytotoxic effects of RSV 3 and RSV $3+\mathrm{ZnO}$ NPs applications were not statistically $(p>0.05)$ different (Figure 1).

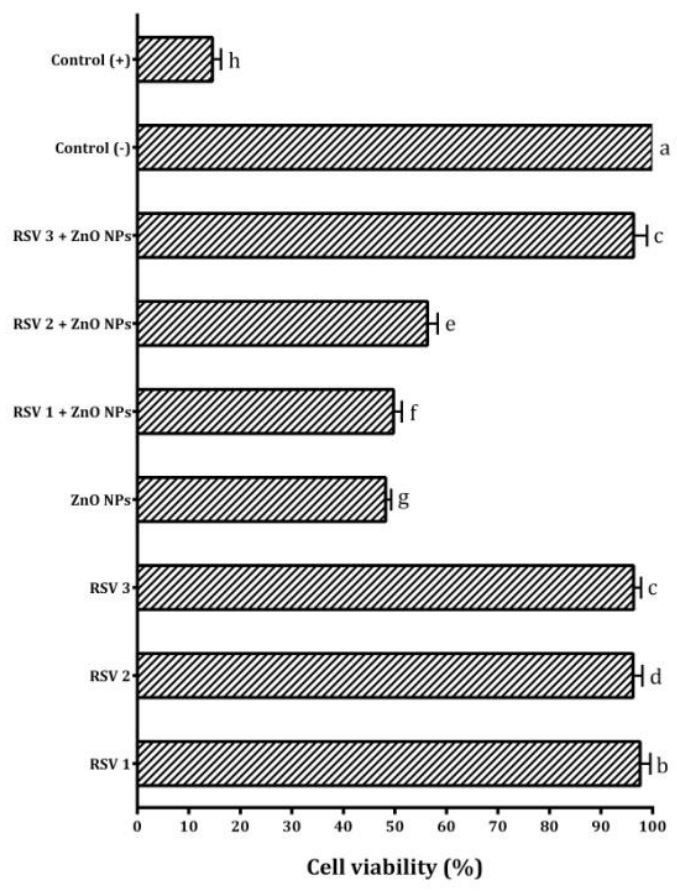

Figure 1. Viability rates in the HPAEpiC exposed to different treatments. Each value is expressed as mean \pm standard deviation $(n=3)$. Values followed by different small letters differ significantly at $p<0.05$

HCA was performed for cytotoxicity of control groups, RSV and ZnO NPs on HPAEpiC. Cytotoxic activities showed that the nine treatments can be divided into three groups (group A, B and C). Group A was larger than those of groups B and C. Control (+) was single treatment in group $\mathrm{C}$ and it had the most distant relationship with the 
other groups. RSV $3+\mathrm{ZnO}$ clustered closely together with control (-) in one branch of the dendrogram. These results indicated that cytotoxicity caused by $\mathrm{ZnO}$ NPs was highly reduced with RSV 3 treatment (Figure 2).

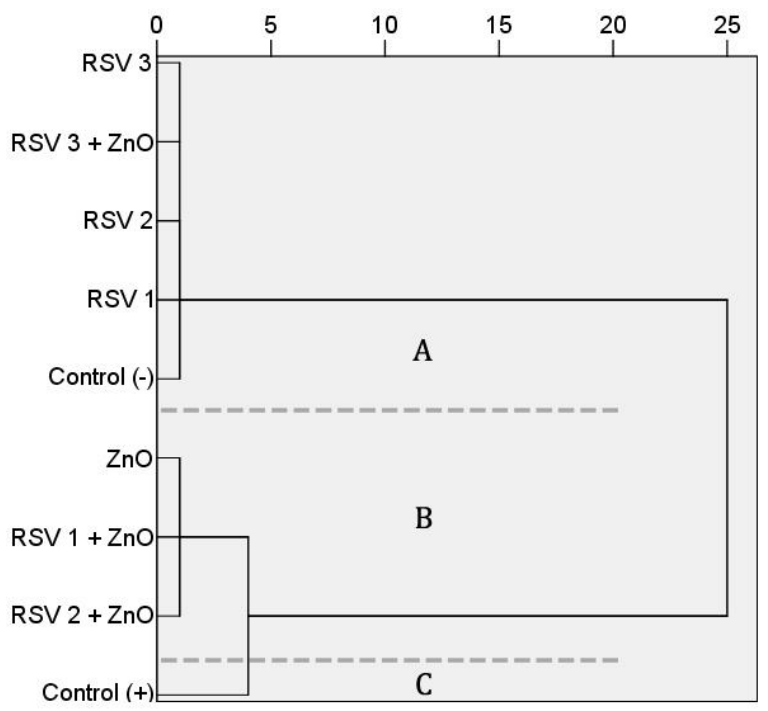

Figure 2. Dendrogram built from cytotoxic effects of different treatments tested on HPAEpiC

\subsection{Genotoxicity activities}

Oxidative stress induced DNA damage emerged in HPAEpiC by RSV and ZnO NPs was measured with 8$\mathrm{OH}-\mathrm{dG}$ level occurring in the cells. It was observed that control (+), RSV 2 and RSV 3 applications significantly ( $p$ $<0.05$ ) increased 8-OH-dG concentrations in the cells. RSV 1 was statistically $(p>0.05)$ indifferent from control (-). RSVs significantly decreased $8-\mathrm{OH}-\mathrm{dG}$ concentrations in ZnO NPs-treated HPAEpiC in a dose dependent manner (Figure 3).

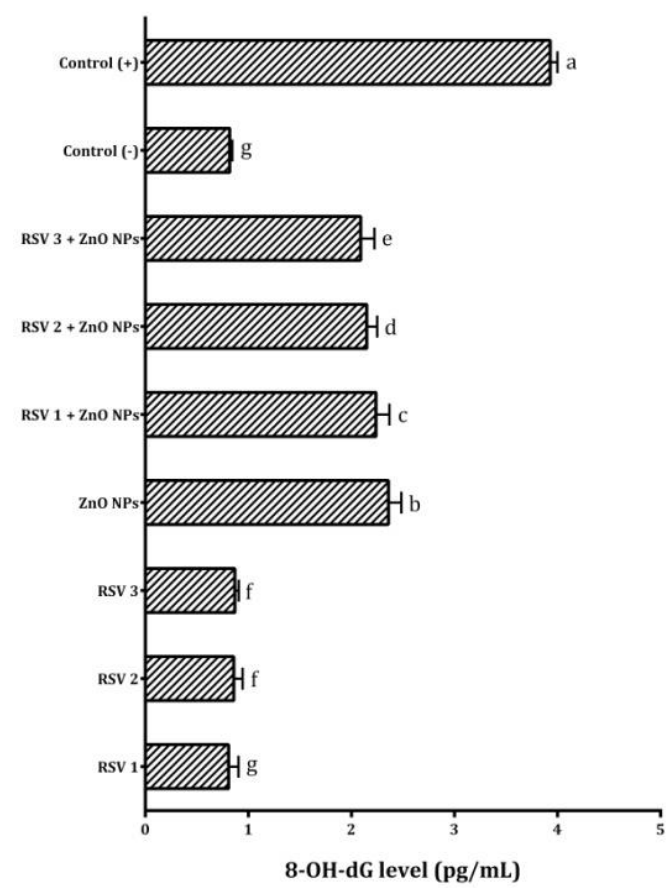

Figure 3. 8-OH-dG adducts in the HPAEpiC exposed to different treatments. Each value is expressed as mean \pm standard deviation $(n=3)$. Values followed by different small letters differ significantly at $p<0.05$

\subsection{Anti-oxidative activities}

Antioxidant capacities of different experiments of RSV and $\mathrm{ZnO}$ NPs on HPAEpiC were detected with TAC analysis. It was detected that TAC value decreased with the addition of $\mathrm{ZnO}$ NPs. Different concentrations of RSV significantly $(p<0.05)$ increased TAC on the cells compared with control (-). TAC levels caused by RSV alone on the cells increased in a concentration-dependent manner. While TAC in HPAEpiC reached the highest level (13.91 mmol Trolox equivalent/L) by ascorbic acid, lowest value (1.13 mmol Trolox equivalent/L) was revealed with $\mathrm{ZnO}$ NPs (Figure 4).

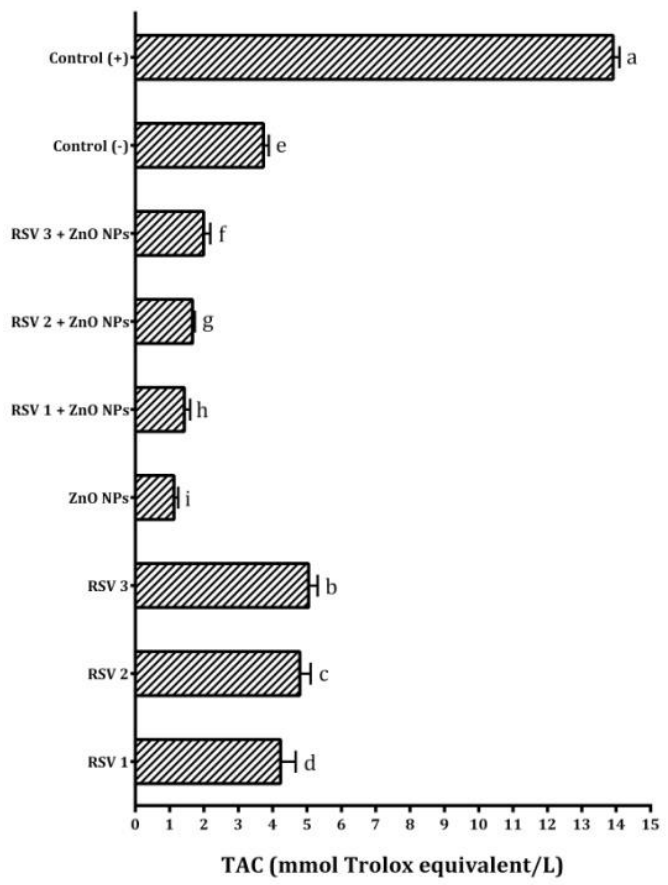

Figure 4. TAC levels in the HPAEpiC exposed to different treatments. Each value is expressed as mean \pm standard deviation $(n=3)$. Values followed by different small letters differ significantly at $p<0.05$

\section{Discussion}

There are many studies showing the negative effects of NPs on humans (Tourinho et al., 2012; Fröhlich and SalarBehzadi, 2014). It has been found that there is a relationship between NPs and respiratory system diseases such as lung cancers, obstructive and interstitial lung diseases (Bonner, 2010). Possible toxic effects of NPs on other organs and systems outside the respiratory system have also been investigated. The toxic effects on the central nervous system are another of these damages. The toxicity that NPs cause as a result of DNA damage disturbs the whole life balance (Glauert et al., 2008). Inhibition of the resulting toxic effects in different areas through natural products is one of the common areas of study (Emsen et al., 2016; Dogan et al., 2017). Especially natural antioxidant components are preferred in this process. Some of these components increase the antioxidant capacity by minimizing oxidative stressinduced damage (Karatas et al., 2015). RSV, one of these important compounds, has been used in many studies. RSV that is a compound in the phenolic structure and has strong antioxidant activity, is used for many treatment process. It was reported that RSV supplementation helped 
to prevent joint damage by reducing inflation in the body (Hao et al., 2017). It has also been shown that resveratrol may be effective in combating various cancer cells such as liver, breast, pancreas and prostate (Carter et al., 2014).

In the present study, 8-OH-dG level measured in the cells showed that $\mathrm{ZnO}$ NPs caused DNA damage in HPAEpiC. At the same time, cytotoxic effects of $\mathrm{ZnO}$ NPs were determined. It was detected that cytotoxic and genotoxic activities of these NPs were significantly high. However, RSV supplementation to cultures with $\mathrm{ZnO}$ NP increased the viabilities rate of the cells. As shown in dendogram in figure 2 , $\mathrm{RSV} 3+\mathrm{ZnO}$ treatment was included with control (-) in one branch. So, RSV 3 was the most critical experiment in terms of reducing $\mathrm{ZnO}$ NP-induced cytotoxicity. Furthermore, ZnO NP-induced genotoxicity could be reduced significantly by the presence of different concentrations of RSV. In previous studies, it was reported that the cytotoxic and genotoxic activities increased in various cells such as MCF-7 (Elavarasan et al., 2017) and MDA-MB-231 human breast cancer cells (Roshini et al., 2017) treated with $\mathrm{ZnO}$ alone. In a research carried out on mouse testicular cells, it was pronounced that $\mathrm{ZnO}$ NPs induced apoptosis through DNA damage caused by reactive oxygen species (Han et al., 2016). There are ZnO NPs induced genotoxicity studies in the literature. Kononenko et al. (2017) revealed that $\mathrm{ZnO}$ NPs caused genotoxicity in vitro in the MadinDarby canine kidney cells. On the other hand, some investigators reported that high oxidative stress caused by $\mathrm{ZnO} \mathrm{NPs}$ in the cells generate oxidant injury, reactive oxygen species (ROS) and excitation of inflammation (Xia et al., 2008). The oxidant substances such as free radicals are inhibited through antioxidant compounds. The level of oxidative stress is reduced due to the increase of the antioxidant capacity in the cells (Birben et al., 2012). Our findings were in line with previous reports. The TAC in the tested cells was increased through a natural antioxidant component, RSV.

The findings of this investigation clearly indicated that RSV modulated ZnO-induced genetic damage in HPAEpiC due to its strong antioxidant and detoxifying nature. Therefore, natural antioxidants could be beneficial against heavy metal poisoning including zinc.

\section{Conflicts of interest}

There is no conflict of interest in any form between the authors.

\section{References}

Birben E, Sahiner UM, Sackesen C, Erzurum S, Kalayci O (2012). Oxidative Stress and Antioxidant Defense. World Allergy Organ J 5: 9-19.

Bonner JC (2010). Nanoparticles as a Potential Cause of Pleural and Interstitial Lung Disease. Proc Am Thorac Soc 7: $138-141$.

Brown DM, Wilson MR, MacNee W, Stone V, Donaldson K (2001). Size-Dependent Proinflammatory Effects of Ultrafine Polystyrene Particles: A Role for Surface Area and Oxidative Stress in the Enhanced Activity of Ultrafines. Toxicol Appl Pharmacol 175: 191-199.

Carter LG, D’Orazio JA, Pearson KJ (2014). Resveratrol and Cancer: Focus on In Vivo Evidence. Endocr Relat Cancer 21: R209R225.

Dogan M, Emsen B, Aasim M, Yildirim E (2017). Ceratophyllum demersum L. Extract as a Botanical Insecticide for Controlling the Maize Weevil, Sitophilus zeamais Motschulsky (Coleoptera: Curculionidae). Egypt J Biol Pest Control 27: 11-15.

Donaldson K, Murphy FA, Duffin R, Poland CA (2010). Asbestos, Carbon Nanotubes and the Pleural Mesothelium: A Review and the Hypothesis Regarding the Role of Long Fibre Retention in the Parietal Pleura, Inflammation and Mesothelioma. Part Fibre Toxicol 7: 5.

Dwivedi PD, Misra A, Shanker R, Das M (2009). Are Nanomaterials a Threat to the Immune System? Nanotoxicology 3: 19-26.

Elavarasan N, Kokila K, Inbasekar G, Sujatha V (2017). Evaluation of Photocatalytic Activity, Antibacterial and Cytotoxic Effects of Green Synthesized ZnO Nanoparticles by Sechium edule Leaf Extract. Res Chem Intermed 43: 3361-3376.

Emsen B, Dogan M, Aasim M, Yildirim E (2016). Insecticidal Activity of In Vitro Propagated Aquatic Plant Ceratophyllum demersum L. against Granary Weevil Sitophilus granarius L. (Coleoptera: Curculionidae). Egypt J Biol Pest Control 26: 619-624.

Emsen B, Turkez H, Togar B, Aslan A (2017). Evaluation of Antioxidant and Cytotoxic Effects of Olivetoric and Physodic Acid in Cultured Human Amnion Fibroblasts. Hum Exp Toxicol 36: 376-385.

Fröhlich E, Salar-Behzadi S (2014). Toxicological Assessment of Inhaled Nanoparticles: Role of In Vivo, Ex Vivo, In Vitro, and in Silico Studies. Int J Mol Sci 15: 4795-4822.

Ghorbani H, Mehr F, Pazoki H, Rahmani B (2015). Synthesis of ZnO Nanoparticles by Precipitation Method. Orient J Chem 31 : 1219-1221.

Glauert HP, Tharappel JC, Lu Z, Stemm D, Banerjee S, Chan LS, Lee EY, Lehmler HJ, Robertson LW, Spear BT (2008). Role of Oxidative Stress in the Promoting Activities of PCBs. Environ Toxicol Pharmacol 25: 247-250.

Han Z, Yan Q, Ge W, Liu Z-G, Gurunathan S, De Felici M, Shen W, Zhang X-F (2016). Cytotoxic Effects of ZnO Nanoparticles on Mouse Testicular Cells. Int J Nanomedicine 11: 5187-5203.

Hao L, Wan Y, Xiao J, Tang Q, Deng H, Chen L (2017). A Study of Sirt1 Regulation and the Effect of Resveratrol on Synoviocyte Invasion and Associated Joint Destruction in Rheumatoid Arthritis. Mol Med Rep 16: 5099-5106.

Karatas M, Dogan M, Emsen B, Aasim M (2015). Determination of In Vitro Free Radical Scavenging Activities of Various Extracts from In Vitro Propagated Ceratophyllum demersum L.. Fresenius Environ Bull 24: 2946-2952. 
Kendall M, Holgate S (2012). Health Impact and Toxicological Effects of Nanomaterials in the Lung. Respirology 17: 743-758.

King RE, Bomser JA, Min DB (2006). Bioactivity of Resveratrol. Compr Rev Food Sci Food Saf 5: 65-70.

Kononenko V, Repar N, Marušič N, Drašler B, Romih T, Hočevar S, Drobne D (2017). Comparative In Vitro Genotoxicity Study of ZnO Nanoparticles, ZnO Macroparticles and ZnCl 2 to MDCK Kidney Cells: Size Matters. Toxicol Vitr 40: $256-263$.

Moezzi A, McDonagh AM, Cortie MB (2012). Zinc Oxide Particles: Synthesis, Properties and Applications. Chem Eng J 185186: $1-22$.

Oztetik E, Aydin E, Sonmez E, Aydin N, Turkez H (2017). Molecular Genetic Responses in Different Human Primary Cell Cultures Exposed to Aluminum-Zinc Oxide Based Nanoparticles In Vitro. J Biotechnol 256: S34-S35.

Özgür Ü, Alivov YI, Liu C, Teke A, Reshchikov MA, Doğan S, Avrutin V, Cho SJ, Morkọ H (2005). A Comprehensive Review of ZnO Materials and Devices. J Appl Phys 98: 1-103.

Roshini A, Jagadeesan S, Cho Y, Lim J, Choi K (2017). Synthesis and Evaluation of the Cytotoxic and Anti-Proliferative Properties of ZnO Quantum Dots against MCF-7 and MDA-MB-231 Human Breast Cancer Cells. Mater Sci Eng C 81: 551-560.

Savouret JF, Quesne M (2002). Resveratrol and Cancer: A Review. Biomed Pharmacother 56: 84-87.

Tourinho PS, van Gestel CAM, Lofts S, Svendsen C, Soares AMVM, Loureiro S (2012). Metal-Based Nanoparticles in Soil: Fate, Behavior, and Effects on Soil Invertebrates. Environ Toxicol Chem 31: 1679-1692.

Turkez H, Geyikoglu F, Yousef MI (2016a). Ameliorative Effects of Docosahexaenoic Acid on the Toxicity Induced by 2,3,7,8Tetrachlorodibenzo-P-Dioxin in Cultured Rat Hepatocytes. Toxicol Ind Health 32: 1074-1085.

Turkez H, Sonmez E, Di Stefano A, Mokhtar YI (2016b). Health Risk Assessments of Lithium Titanate Nanoparticles in Rat Liver Cell Model for Its Safe Applications in Nanopharmacology and Nanomedicine. Cytotechnology 68: 291-302.

Xia T, Kovochich M, Liong M, Mädler L, Gilbert B, Shi H, Yeh JI, Zink JI, Nel AE (2008). Comparison of the Mechanism of Toxicity of Zinc Oxide and Cerium Oxide Nanoparticles Based on Dissolution and Oxidative Stress Properties. ACS Nano 2: 2121-2134.

Zhao J, Castranova V (2011). Toxicology of Nanomaterials Used in Nanomedicine. J Toxicol Environ Heal - Part B Crit Rev 14: 593-632.

Cite this article: Emsen B, Turkez H (2017). The protective role of resveratrol against zinc oxide induced nanotoxicity. Anatolian Journal of Botany 1(2): 21-25. 